\title{
Use of Inoculator Bacteria to Promote Tuber melanosporum Root Colonization and Growth on Quercus faginea Saplings
}

\author{
Yasmine Piñuela ${ }^{1,2, *} \mathbb{\infty}$, Josu G. Alday ${ }^{1,3}{ }^{\oplus}$, Daniel Oliach ${ }^{2} \oplus$, Francesc Bolaño ${ }^{2}$, \\ Carlos Colinas ${ }^{1,2}$ and José Antonio Bonet ${ }^{1,3}$ (D) \\ 1 Department of Crop and Forest Sciences, University of Lleida, Av. Alcalde Rovira Roure 191, 25198 Lleida, \\ Spain; josu.alday@udl.cat (J.G.A.); carlos.colinas@udl.cat (C.C.); jantonio.bonet@udl.cat (J.A.B.) \\ 2 Forest Science and Technology Centre of Catalonia, Crta. Sant Llorenç de Morunys km 2, 25280 Solsona, \\ Spain; daniel.oliach@ctfc.cat (D.O.); francesc.bolano@ctfc.cat (F.B.) \\ 3 Joint Research Unit CTFC-AGROTECNIO, Av. Alcalde Rovira Roure 191, 25198 Lleida, Spain \\ * Correspondence: yasmine.pinuela@udl.cat
}

Received: 22 June 2020; Accepted: 20 July 2020; Published: 22 July 2020

\begin{abstract}
Research Highlights: Mycorrhizal helper bacteria (MHB) promote mycorrhization processes and are commonly found in the mycorrhizosphere of fungi, such as the edible hypogeous fungus Tuber melanosporum Vittad. Background and Objectives: The effectiveness of MHB in promoting the mycorrhization process and the root development of Portuguese oak (Quercus faginea Lam.) seedlings destined for truffle plantations has not been determined. The main aim of this study was to shed light on the effect of bacterial inoculation on fungal root tip colonization and seedling root traits. Material and methods: We performed a co-inoculation trial using three bacteria naturally present in the T. melanosporum niche (i.e., Pseudomonas fluorescens, Pseudomonas putida, and Bacillus amyloliquefaciens) and two different bacterial inoculation times (one month and nine months after fungal inoculation) under glasshouse conditions. Results: Only P. fluorescens had a significant mycorrhizal promoter effect, increasing the truffle inoculation rates of root tips by more than $10 \%$ compared with seedlings that received non-bacterial inoculation treatments. Simultaneously, the co-inoculation of $P$. fluorescens with T. melanosporum improved seedling root growth parameters compared with those of seedlings that received non-bacterial inoculation treatments. The different bacterial inoculation times and applications of uninoculated bacterial growth media did not affect the root traits analyzed or the root mycorrhization rates. Conclusions: These results suggest that $P$. fluorescens bacteria have a potential commercial application as a treatment for truffle-inoculated seedlings to improve both seedling quality and mycorrhizal colonization under nursery conditions.
\end{abstract}

Keywords: black truffle; truffle colonization; edible fungi cultivation; truffle orchard; truffle trees; hypogeous ectomycorrhizal fungi

\section{Introduction}

The hypogeous fruiting bodies of fungal species in the Tuber genus form ectomycorrhizal (ECM) associations with angiosperms and gymnosperms worldwide [1]. Many Tuber species are suitable for human consumption, including the highly prized black truffle (Tuber melanosporum Vittad.). Due to its unique aroma and flavor, the black truffle is one of the world's top culinary delicacies [2]. Therefore, owing to its socioeconomic interest, the black truffle has been targeted as a high-value resource for years, leading to a reduction in wild yields, mainly because of overexploitation, as well as land-use changes and global warming [3,4]. Since the dramatic drop in wild black truffle harvests in the 20th 
century, production rates have been gradually compensating due to effective cultivation since the 1970s [5].

Truffle cultivation involves inoculating specific host-tree seedlings in the nursery with a truffle inoculum, and then planting these seedlings in areas with suitable conditions for the development of the fungus [6]. In the inoculation process, fungal spores need to make contact with the seedling's fine roots so that when the spores germinate, they form mycorrhizae with emerging root tips, establishing symbiotic associations [7]. Consequently, the use of high truffle inoculation rates is recommended on seedlings intended for planting, with the minimum percentage of $30 \%$ T. melanosporum mycorrhizal root tips indicated as a prerequisite that slightly varies depending on the methodology used for mycorrhizal seedling evaluation [8-10]. Different inoculation methods have been developed to increase the mycorrhization rate of black truffle in seedlings, such as the use of soil from productive trees [11] or the use of mycelial culture techniques [12]. However, mycorrhizal formation is not just a bipartite interaction between the fungus and the plant, as other soil microorganisms are also present, such as other fungi, including yeasts [13], molds [14], saprophytic fungi [15], and, most importantly, bacteria, some of which are recognized as mycorrhizal helper bacteria (MHB) due to their capacity to facilitate the formation of mycorrhiza by stimulating mycelial extension, incrementing the contact between the fungus and the root tips of its associated symbiont and, simultaneously, by lowering the effect of adverse environmental conditions [16].

MHB have been identified in several species in the Tuber genus, either isolated from ECM root tips, such as in the case of T. aestivum [17] and T. borchii [18], or identified in the ascomata biome of T. borchii [19], T. magnatum [20], and T. oregonense [21]. Different MHB, such as Bacillus sp. (phylum Firmicutes) and Pseudomonas sp. (phylum Gammaproteobacteria), have been found at different stages of the T. melanosporum life cycle, e.g., from mycorrhiza formation to sporocarp development $[14,22,23]$. However, the influence of specific MHB during the early stages of root tip colonization by T. melanosporum are still to be elucidated.

Among the few studies that have focused on the positive effects of MHB on T. melanosporum root tip colonization, Domínguez et al. [24] showed that T. melanosporum colonization rates of Pinus halepensis roots doubled when co-inoculated with Pseudomonas fluorescens. Similarly, Mamoun and Olivier [25] analyzed the effect of $P$. fluorescens and P. putida on truffle mycorrhization rates of Corylus avellana roots. Although after 6 months both bacteria were observed to have an antagonistic effect on truffle mycorrhization rates, one year later truffle colonization rates were highest for those seedlings co-inoculated with T. melanosporum and one specific strain of P. putida (isolate pu. 4-1). Surprisingly, the positive co-inoculation effects of a bacterial and truffle inoculum in a host species belonging to the Quercus genus have not been investigated to date, even though oaks are the most commonly used truffle-inoculated trees, especially in Mediterranean areas [26].

The aims of this study were: (i) To obtain insights into whether co-inoculations of T. melanosporum with different MHB influenced the fungal root tip colonization rate of Quercus faginea; (ii) to observe the effect of bacterial inoculation on $Q$. faginea root development; and (iii) to perform an inoculation time test to determine whether the bacterial application time influenced the outcomes. Based on the satisfactory mycorrhizal colonization of $P$. halepensis and C. avellana roots reported by Domínguez et al. [24] and Mamoun and Olivier [25], respectively, when T. melanosporum was co-inoculated with Pseudomonas, we selected P. fluorescens and P. putida for co-inoculation with T. melanosporum. A third bacteria, Bacillus amyloliquefaciens, was also selected because it is naturally abundant in the mycorrhizosphere and surrounding bulk soil $[23,27]$ and has also been described as an MHB [28]. We expected that bacteria co-inoculation of seedlings would enhance the formation of mycorrhizal root tips. Furthermore, given that the bacteria used here have also been reported to be plant growth-promoting bacteria $[24,29,30]$, we hypothesized that seedling root growth would be enhanced when truffle-inoculated roots were co-inoculated with bacteria. In parallel, because the bacterial community is very dynamic in soil [22,23], bacterial inoculations were performed one month and nine months after T. melanosporum inoculation to determine whether the application time influenced the 
outcomes. Some previous studies have developed methods involving the simultaneous co-inoculation of bacteria and fungi [24,31]; however, here, we avoided using a simultaneous inoculation method to assess whether co-inoculation really promotes mycorrhizal formation after a symbiotic association has already formed [32].

\section{Materials and Methods}

\subsection{Experimental Design}

The experiment followed a completely randomized design with two factors: (a) Bacterial inoculation (seven levels) and (b) time of inoculation (two levels). The culture of bacteria requires specific formulations of growth media. Hence, in order to discount the growth medium in which bacteria were cultured as the cause of increased mycorrhizal formation or root growth rather than the bacteria itself, we included one control per bacterial species in which only the growth medium was applied to the seedling. Therefore, there were seven inoculation treatments: The three bacteria selected for the experiment (P. fluorescens, P. putida, and B. amyloliquefaciens) in their respective growth medium, the three growth media without bacteria, and a control treatment that was not inoculated with growth media or bacteria. In addition, for each inoculation type, there were two bacterial inoculation times: One month (T1) or nine months (T2) after T. melanosporum inoculation (Figure 1). Thus, an experimental unit consisted of a single seedling that was inoculated with one of the following treatments (inoculum type): (1) P. fluorescens (F), (2) P. putida (P), (3) B. amyloliquefaciens (B), (4) the P. fluorescens growth medium (CF), (5) the P. putida growth medium (CP), (6) the B. amyloliquefaciens growth medium (CB), each one only inoculated at inoculation time T1 or T2 and (7) a control seedling inoculated exclusively with T. melanosporum (CS) with no bacterial inoculation at T1 or T2. A total of 260 seedlings were used in the experiment (with 20 replicates of each treatment: FT1, FT2, PT1, PT2, BT1, BT2, CFT1, CFT2, CPT1, CPT2, CBT1, CBT2, and CS). To avoid any possibility of cross contamination among treatments, experimental seedlings were surrounded by eight standard seedlings in the nursery trays. In July 2018 (13 months after truffle inoculation), 12 plants per treatment were randomly selected to assess root colonization by ECM fungi as this usually corresponds with the minimum period of mycorrhizal development at which truffle-inoculated seedlings grown for commercial sale are sold. From these 12 plants, 5 were randomly selected for root trait assessment prior to the assessment of ECM root colonization.

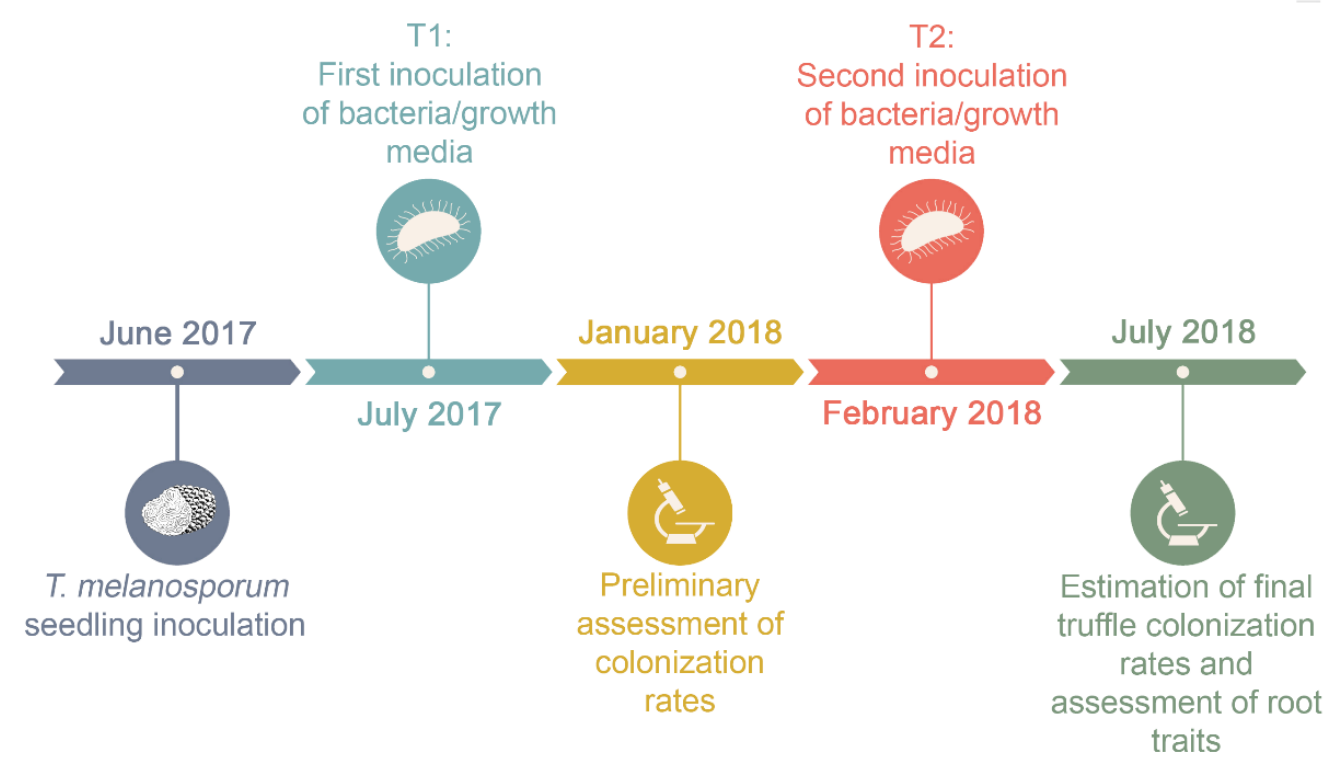

Figure 1. Timeline of the bacteria and truffle co-inoculation experiment performed in a commercial nursery (Vilanova de Meià, Lleida, Spain) between June 2017 and July 2018. 


\subsection{Plant Material and Bacterial Inoculum}

Portuguese oak seedlings (Q. faginea Lam.) grown under glasshouse conditions that had been recently inoculated with $T$. melanosporum were supplied by a commercial nursery located in Vilanova

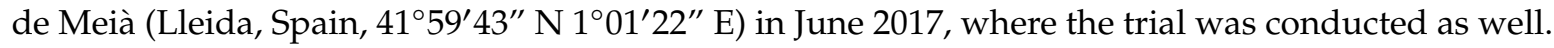
Glasshouse temperatures ranged from $20-30^{\circ} \mathrm{C}$ during the hottest months (July, August, and September 2017) to $5-10^{\circ} \mathrm{C}$ in winter months (November, December 2017 and January, February 2018). A sprinkler system running through the ceiling was used for watering the seedlings. Plants were located $1 \mathrm{~m}$ in height above the ground in order to prevent root coiling. All the plants were from the same nursery lot in order to use plants with homogeneous characteristics in terms of seed provenance, inoculum source, date of inoculation, and seedling age (the plants were one year old at the date of inoculation) and to reduce the likelihood that the genetic variability of the fungal inoculum or plant provenance could influence the mycorrhization process [33]. We used Full-Pot ${ }^{\circledR}$ containers and culture substrates with vermiculite and a mixture of Sphagnum peat moss (black type), $\mathrm{pH}=7$, in a 3:1 ratio of peat/vermiculite to obtain a porous and permeable substrate. No additional fertilization was added to the substrate.

P. fluorescens CECT 844, P. putida CECT 8043, and B. amyloliquefaciens CECT 5686 strains were provided by CECT (Spanish Type Culture Collection, University of Valencia, Valencia, Spain). A different standard nutrient medium was used for each bacterial species following the recommendations of CECT: P. fluorescens was grown on a peptone-yeast medium (1 g of beef extract, $2 \mathrm{~g}$ of yeast extract, $5 \mathrm{~g}$ of peptone, $5 \mathrm{~g}$ of $\mathrm{NaCl}$, and $15 \mathrm{~g}$ of agar in $1 \mathrm{~L}$ of distilled water), P. putida was grown on trypticase soy broth medium (17 $\mathrm{g}$ of tryptone, $3 \mathrm{~g}$ of soy peptone, $2.5 \mathrm{~g}$ of $\mathrm{K}_{2} \mathrm{HPO}_{4}$, and $5 \mathrm{~g}$ of $\mathrm{NaCl}$ in $1 \mathrm{~L}$ of distilled water), and B. amyloliquefaciens was grown on agar medium ( $5 \mathrm{~g}$ of beef extract, $10 \mathrm{~g}$ of peptone, $5 \mathrm{~g}$ of $\mathrm{NaCl}$, and $15 \mathrm{~g}$ of agar in $1 \mathrm{~L}$ of distilled water). To prepare the final liquid inoculum of bacteria, a single colony of each bacterium was incubated first in $100 \mathrm{~mL}$ of its respective liquid medium for $16 \mathrm{~h}\left(140 \mathrm{rpm}, 30^{\circ} \mathrm{C}\right)$, and then diluted in $500 \mathrm{~mL}$ of fresh medium, and cultivated under the same conditions for $18 \mathrm{~h}$. Bacterial growth media used as controls $(\mathrm{CF}, \mathrm{CP}$, and $\mathrm{CB}$ ) were prepared simultaneously (at a final volume of $500 \mathrm{~mL}$ ). The final inoculum was applied by injecting a dose of $10 \mathrm{~mL} /$ seedling into the substrate at the two bacterial inoculation times (July 2017 and February 2018, corresponding to T1 and T2, respectively). The second bacterial inoculation time was chosen based on when the presence of $T$. melanosporum root tips could be easily detected using binocular microscopy (beginning of February), and was performed in the same way as the first bacterial inoculation (Figure 1).

In order to determine the final concentration of bacterial inoculum, immediately before the inoculum was applied to seedlings, the final liquid inoculum was plated onto solid medium and serial dilutions were performed to estimate the number of colony forming units (CFUs) after $24 \mathrm{~h}$ of incubation. Final concentrations were estimated to be $1 \times 10^{8} \mathrm{CFU} / \mathrm{mL}$ for P. fluorescens, $3 \times 10^{8} \mathrm{CFU} / \mathrm{mL}$ for P. putida, and $5 \times 10^{8} \mathrm{CFU} / \mathrm{mL}$ for B. amyloliquefaciens.

\subsection{Seedling Root Trait Analyses}

Root traits assessment was performed by analyzing the image of the root system of every seedling selected (five per treatment: in total 65 seedlings) using the software WinRHIZO ${ }^{\circledR}$ (Regent Instruments Inc., Quebec City, QC, Canada), an image analysis system designed for automatic root measurements.

To scan the root system of every seedling selected, the roots were severed from the shoot at the root collar and inserted into a Plexiglas tray filled with water. The lateral roots were separated from each other and spaced out all over the tray so that roots were not overlapping during the scanning process. The tray was placed on the surface of the scanner (Epson Perfection V700 Photo Scanner system, Epson America, Inc., Long Beach, CA, USA) to capture an image of the root sample.

Root traits analyzed were total root length (calculated using a one pixel thinned image and multiplying the number of pixels by pixel size), average root system diameter (calculated by dividing the projected area of the imaged root by the total length), root surface area (calculated by determining the root diameter and length), and root volume (calculated using the root surface area and length) [34]. 


\subsection{Estimation of T. melanosporum Colonization Rates}

We estimated mycorrhizal colonization of selected seedlings (12 per treatment: 156 in total) following the method developed by Fischer and Colinas [10]. In brief, the whole root system of a plant was cut into small pieces $(2 \mathrm{~cm})$ and placed on a tray. In the bottom of the tray, we placed a grid $(1 \mathrm{~cm} \times 1 \mathrm{~cm}$ squares, formed by four groups of the same number of squares, which were evenly distributed, with a different color for each group) and the roots were evenly distributed across the grid. The method consisted of selecting one color randomly and counting the T. melanosporum root tips within this group under a stereo microscope (Leica WILD MZ8 C). To characterize and identify T. melanosporum mycorrhizae or other possible ECM species that might be present, we used Agerer's Colour Atlas of Ectomycorrhizae [35]. DNA extraction and amplification of the internal transcribed spacer region was performed when a mycorrhiza could not be identified based on morphological observations alone [2].

\subsection{Statistical Analyses}

Seedlings with less than $10 \%$ of their root tips mycorrhized with T. melanosporum were considered culls and omitted from the analyses (in total, 12 out of 156 seedlings were omitted). Low-quality images of seedlings due to root overlapping in the scanning process were omitted from root traits analyses (in total, 8 seedlings were omitted). All statistical analyses were implemented in the R software environment (version 3.6.1; R Development Core Team, 2019). Prior to any analyses, the T. melanosporum mycorrhization rates were square root transformed to meet the homoscedasticity criteria. Afterwards, ANOVAs were used to test the effect of bacteria, growth media, and the two inoculation times on T. melanosporum inoculation rates and root traits. A preliminary ANOVA analysis showed that inoculation time had no effect on mycorrhization rates; therefore, we decided to group together both times for simplicity. When significant differences were found, pairwise comparisons were checked using a post-hoc Tukey's test.

\section{Results}

\subsection{Effects of Bacteria and Inoculation Time on T. melanosporum Root Tip Colonization Rates}

Identification of T. melanosporum mycorrhizae was performed successfully using the Agerer's Colour Atlas of Ectomycorrhizae [35]. Mycorrhiza from other non-target ectomycorrhizal species (including here other fungi species belonging to the genera Tuber) were not identified. The bacterial inoculation time did not appear to have any interactive effect on mycorrhization rates $\left(\mathrm{F}_{[1,129]}{ }^{\mathrm{value}}=0.04\right.$, $p=0.84)$; thus, we decided that mycorrhization data obtained for both bacterial inoculation times (T1 and T2) for each type of inoculation treatment should be grouped together for further analysis (Table 1). Analysis of the effect of individual bacteria on T. melanosporum root tip colonization rates (Table 1 ) showed that colonization rates ranged from a minimum of $25.4 \% \pm 2.7 \%$ of root tips colonized by T. melanosporum, which was recorded for control seedlings (CS), to a maximum of $35.1 \% \pm 1.6 \%$ of root tips colonized by T. melanosporum, which was recorded for seedlings inoculated with P. fluorescens (F). Significant differences were found between the $P$. fluorescens treatment $(F)$ and the uninoculated control (CS) ( $p=0.06, \mathrm{CI}$ at 90\%). However, the average T. melanosporum root tip colonization rate of bacteria co-inoculated seedlings (i.e., F, P, and B treatments) was not significantly different to that of seedlings inoculated with just the growth media (i.e., CF, CP, and CB treatments) $(p=0.66$ ). Overall, all bacteria-inoculated seedlings tended to have a greater proportion of truffle mycorrhizal root tips compared with seedlings inoculated with just their respective growth media. An exception was found for P. putida: seedlings co-inoculated with the P. putida growth medium (CP) or P. putida (P) had a similar proportion of T. melanosporum-colonized root tips $(32.9 \pm 2.5$ and $33.0 \pm 2.0 \%$, respectively) (Table 1). 
Table 1. Mycorrhization rates of Quercus faginea root tips by Tuber melanosporum (\% \pm SE) after co-inoculation with bacteria and truffle inocula in a commercial nursery (Vilanova de Meià, Lleida, Spain) between June 2017 and July 2018. Average mycorrhization rates ( $\% \pm$ SE) of all seedlings for each inoculation treatment (bacteria in a growth medium or the bacterial growth medium without bacteria) are also shown. Different letters in the same column indicate significant differences between the mean values of different treatments $(p<0.05)$.

\begin{tabular}{cccc}
\hline $\begin{array}{c}\text { Bacterial } \\
\text { Inoculation } \\
\text { Treatment }\end{array}$ & Bacteria/Growth Media & $\begin{array}{c}\text { T. melanosporum } \\
\text { Mycorrhization } \\
\text { Rates (\%) }\end{array}$ & $\begin{array}{c}\text { Average Mycorrhization } \\
\text { Rates (\%)/Inoculation } \\
\text { Treatment Type }\end{array}$ \\
\hline Bacteria in growth & $\begin{array}{c}\text { Pseudomonas fluorescens (F) } \\
\text { Pseudomonas putida (P) } \\
\text { media }\end{array}$ & $\begin{array}{c}35.1 \pm 1.6 \mathrm{a} \\
\text { Bacillus amyloliquefaciens (B) }\end{array}$ & $32.9 \pm 2.5 \mathrm{ab}$ \\
\hline Growth media & P. fluorescens growth medium (CF) & $26.8 \pm 1.8 \mathrm{~b}$ & $33.4 \pm 1.4 \mathrm{a}$ \\
without bacteria & P. putida growth medium (CP) & $33.0 \pm 2.0 \mathrm{ab}$ & $29.6 \pm 1.2 \mathrm{a}$ \\
& B. amyloliquefaciens growth & $29.1 \pm 2.5 \mathrm{ab}$ & \\
\hline mo inoculation & Control seedlings (CS) & $25.4 \pm 2.7 \mathrm{~b}$ & \\
\hline
\end{tabular}

\subsection{Bacteria and Inoculation Time Effects on Seedling Root Traits}

The seedling root traits measured in the experiment were not affected by either the bacterial inoculation time (average root system diameter: $\mathrm{F}_{[1,41]}$ value $<0.00, p=0.99$; root length: $\mathrm{F}[1,41]$ value $=0.52, p=0.48$; root surface area: $\mathrm{F}_{[1,41]}$ value $=0.32, p=0.58$; root volume: $\mathrm{F}_{[1,41]}$ value $=0.12, p=0.73$ ) or the bacterial growth media. Therefore, root traits observed at both inoculation times for each inoculation treatment were grouped together for analysis as previously described for T. melanosporum mycorrhization rates.

Although the average root system diameter of seedlings inoculated with P. fluorescens tended to be larger than those of seedlings that received other treatments, it was not significantly different to that of seedlings that received the CS treatment $(p=0.66)$. However, the average root system diameter of seedlings inoculated with $P$. fluorescens (F treatment) was significantly different to those that received the $C P$ treatment $(163.37 \pm 1.91 \mathrm{~mm}$ compared with $155.0 \pm 1.71 \mathrm{~mm}$, respectively) $(p=0.03)$ (Figure 2a). Furthermore, the root length of $P$. fluorescens-inoculated seedlings was significantly greater than that of seedlings that received the control (CS) treatment $(p=0.02)(26.2 \pm 0.2 \mathrm{~cm}$ compared with $24.4 \pm 0.2 \mathrm{~cm}$, respectively) and seedlings inoculated with P. fluorescens developed the longest roots (Figure 2b).

Root surface area measurements ranged from $1212.7 \pm 9.5 \mathrm{~cm}^{2}$ for non-inoculated seedlings (CS) to $1335.7 \pm 20.0 \mathrm{~cm}^{2}$ for seedlings co-inoculated with $P$. fluorescens. The root surface area of seedlings co-inoculated with $P$. fluorescens was significantly greater than that of the control seedlings (CS) and seedlings co-inoculated with bacterial growth media (CP and CB; $p<0.01$ ), except for the P. fluorescens growth media $(C F)$ treatment $(p=0.53)$. Furthermore, the root surface area of seedlings inoculated with $P$. fluorescens was significantly greater than that of seedlings inoculated with B. amyloliquefaciens $(p=0.03$; Figure 2c).

The root volume measurements ranged from $4704.2 \pm 106.2 \mathrm{~cm}^{3}$ for seedlings that received the CP treatment to $5462.0 \pm 144.3 \mathrm{~cm}^{3}$ for seedlings co-inoculated with $P$. fluorescens, a difference of more than $10 \%$. Furthermore, the root volume of seedlings inoculated with P. fluorescens was significantly greater than that of seedlings that received the CP $(p<0.01)$ or CB treatments $(p<0.01$; Figure $2 \mathrm{~d})$. 
(a)

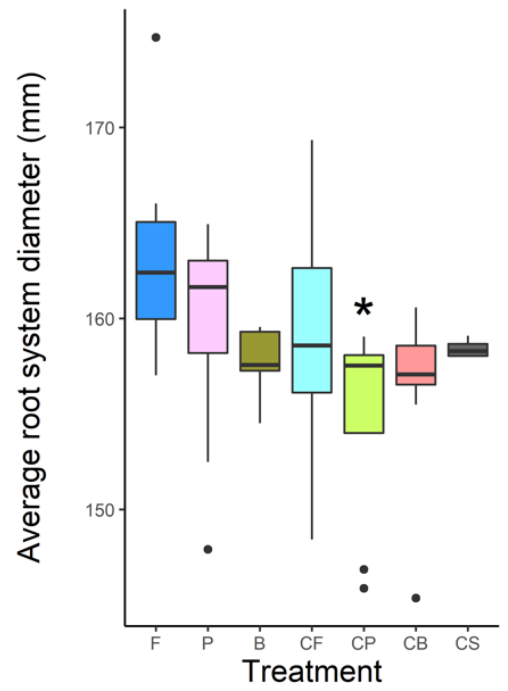

(c)

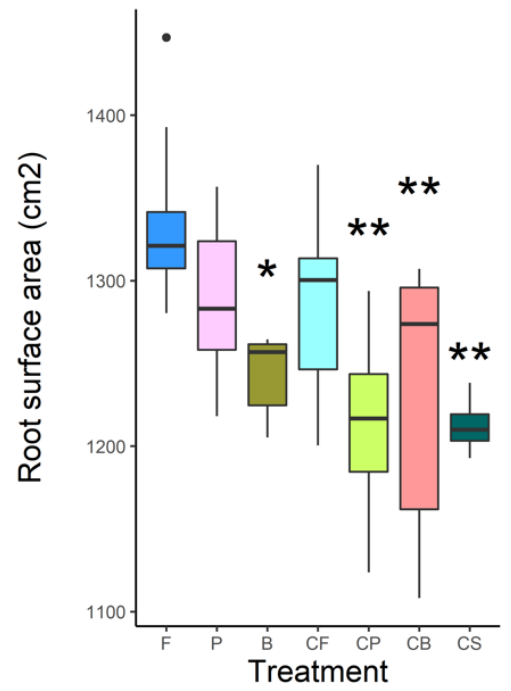

(b)

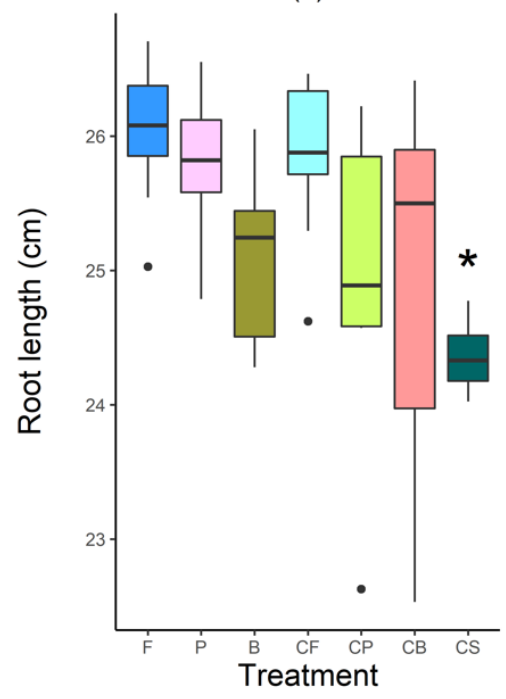

(d)

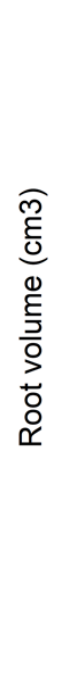

Treatment

由. fluorescens

官 P. putida

B. amyloliquefaciens

官 Control P. fluorescens

官 Control P. putida

Control B. amyloliquefaciens

Control

Figure 2. Root traits of Quercus faginea seedlings in a commercial nursery (Vilanova de Meià, Lleida, Spain) inoculated with Tuber melanosporum and then co-inoculated with either bacteria in growth media or growth media without bacteria between June 2017 and July 2018. (a) Average root system diameter $(\mathrm{mm}),(\mathbf{b})$ root length $(\mathrm{cm}),(\mathbf{c})$ surface area $\left(\mathrm{cm}^{2}\right),(\mathbf{d})$ root volume $\left(\mathrm{cm}^{3}\right)$ evaluated under the different treatments: Pseudomonas fluorescens in growth medium (F), Pseudomonas putida in growth medium (P), Bacillus amyloliquefaciens in growth medium (B), P. fluorescens growth medium control (CF), P. putida growth medium control (CP), B. amyloliquefaciens growth medium control (CB), and control seedlings (CS) that were not inoculated with bacteria or a bacterial growth medium. $p$-values $\left(^{* *} p<0.01\right.$ and $* p<0.05)$ are indicated above boxplots to indicate specific treatments that resulted in significantly lower root trait values than that of seedlings that were co-inoculated with P. fluorescens (F).

\section{Discussion}

Our results revealed that among the three bacterial strains (i.e., P. fluorescens CECT 844, P. putida CECT 8043, and B. amyloliquefaciens CECT 5686) assessed in the present trial, P. fluorescens promoted both T. melanosporum mycorrhizal development and $Q$. faginea seedling root development the most effectively. Overall, all seedlings co-inoculated with bacteria tended to have better mycorrhization rates than those that were only inoculated with T. melanosporum (control, CS); however, only seedlings co-inoculated with $P$. fluorescens showed significantly greater colonization rates than the control seedlings. P. fluorescens also showed a slight root growth-promoting effect, resulting in significantly 
higher average values for the total root system length and root surface area compared with CS seedlings. Root system diameter and root volume average values tended to be higher at $P$. fluorescens-inoculated seedlings; however, these values were not significantly different to those obtained for the control treatment. Bacteria inoculation time did not affect root tip colonization rates by T. melanosporum or the seedling root traits that were analyzed. Finally, we also demonstrated that the bacterial growth media used to culture the bacteria did not promote root growth or black truffle mycorrhizal development.

We included B. amyloliquefaciens in the co-inoculation experiment because of its co-occurrence in natural habitats at the T. melanosporum-root interface [14,22,23]. However, our results showed that co-inoculating B. amyloliquefaciens did not influence either seedling mycorrhization rates or seedling root development, at least not at this mycorrhizal establishment phase. However, as shown in previous studies of other ECM species, such a co-existence might not indicate a functional interaction between organisms. For instance, Oh and Lim [36] isolated different bacteria in a Tricholoma matsutake environment (i.e., within the 'fairy rings' formed by T. matsutake), finding that among all the bacteria isolated from fairy rings, only a Paenibacillus bacteria improved the proliferation of the ECM (under culture conditions). In the case of truffles, Gryndler et al. [37] observed that bacteria (among other organic and inorganic compounds tested) previously isolated from ECM root tips of T. aestivum [17] had no effect on the mycorrhizal growth of T. aestivum mycelium under culture conditions.

In the same way, we observed that P. putida did not promote mycorrhizal development or root growth, at least the specific strain used for inoculation in the present trial (P. putida CECT 8043). These results are contrary to those reported by Mamoun and Olivier [25], in which the highest colonization rates for T. melanosporum were observed after a year of co-inoculation with one specific strain of P. putida among the different strains belonging to P. putida and P. fluorescens tested in their greenhouse experiment. In the trial performed by Mamoun and Olivier [25], the soil substrate used for seedling cultivation and the bacteria used for seedling inoculation were also obtained/isolated from an adjacent experimental truffle orchard (INRA, Dordogne, France) from the same tree species used for the inoculation experiment, i.e., Corylus avellana. Some isolates of Pseudomonas appeared to be more efficient than others as only seedlings inoculated with one particular strain of $P$. putida showed higher mycorrhization rates than seedlings inoculated with the rest of the isolated bacteria and the control seedlings.

Therefore, we hypothesize that the fungus selects a specific bacterium among all the bacteria present in its microbiome [23,38] that is potentially beneficial for a certain function during its lifecycle. Frey-Klett et al. [39] observed that P. fluorescens strains isolated from the mycosphere of Laccaria bicolor had a phosphate-solubilizing function unlike strains isolated from bulk soil, as well as a lower intraspecific diversity in the mycosphere compartment than in the bulk soil, suggesting that the bacterial community (of different $P$. fluorescens strains) is the result of selection by the ECM fungus according to fungal-plant necessities. Antony-Babu et al. [22] detected lower levels of bacterial diversity in T. melanosporum sporocarps than in the bulk soil. Bacterial communities in sporocarps were dominated by the genus Bradyrhizobium; however, in the bulk soil, Bradyrhizobium represented less than $1 \%$ of the bacteria detected. Antony-Babu et al. [22] hypothesized a selection process for this specific bacterium from the ectomycorrhizosphere, which is beneficial to sporocarp formation. Bradyrhizobium may have a similar effect on different truffle species because it has also been reported in sporocarps of T. borchii [19] and T. magnatum [20]. Moreover, Deveau et al. [23] detected a stable bacterial community composition associated with ectomycorrhizal root tips over five consecutive months, which may be due to the selection of specific bacteria implicated in the mycorrhization process. Therefore, we believe that even though P. putida and B. amyloliquefaciens have been reported to co-occur with T. melanosporum, their presence does not seem to be as a result of a fungal-bacterial interaction.

In the 1980s, strains belonging to the Pseudomonas genus were also reported to be plant growth-promoting rhizobacteria [40]. Since then, numerous studies, mostly of agricultural crops, have demonstrated that particular strains of Pseudomonas are beneficial for plant growth $[29,41]$. In the case of ECM fungi, the root growth-promoting effect of Pseudomonas strains in combination with 
Laccaria bicolor has been observed after the addition of the ECM-bacterial complex to its host tree partner Populus deltoides: An increase in lateral root formation compared with seedlings growing under axenic conditions was observed [42]. Rincón et al. [43] reported that the co-inoculation of Pinus halepensis with Suillus granulatus and P. fluorescens led to an increase in the seedling tap-root length and in the number of lateral roots; however, this did not occur when these microorganisms were inoculated separately. Domínguez et al. [24] reported similar results for the P. halepensis root system when T. melanosporum was co-inoculated with $P$. fluorescens, which led to an improvement in the growth of almost all root parameters. Indeed, the phosphate-solubilizing function, together with indole- 3 acetic acid production, are among the plant growth-promoting traits described for P. fluorescens [30]. Our results agree with the findings of these previous studies given that co-inoculation of T. melanosporum with $P$. fluorescens significantly increased the root length and root surface area relative to those of non-inoculated seedlings.

Furthermore, even though bacterial growth media inoculations were a source of nutrients and could positively affect seedling roots as a fertilizer, promoting plant growth and/or mycorrhization rates, we did not observe any differences in the mycorrhization rates or root seedling traits when bacterial growth media were added to the seedling substrate compared with that of control seedlings. To the best of our knowledge, none of the T. melanosporum and bacteria co-inoculation trials performed to date have assessed the possible effects of bacterial growth media on either fungal colonization or root development [24,25,31].

\section{Conclusions}

At present, although high-throughput databases of soil bacteria are growing along with more information about different microorganisms associated with fungal life stages, knowledge about mycorrhizosphere biological interactions is still sparse [16]. We believe that understanding mechanisms derived from the bacterial-fungal association that are involved in enhancing mycorrhization is essential for the exploitation of these symbioses to improve the quality of truffle-inoculated seedlings. However, it is crucial that future research studies combine species community assessments of bacterial-fungal associations with bacterial culture-based methods, which are essential to observe MHB effects on fungi [38]. These methods consist of isolating a bacterium directly from a specific compartment of the target fungus (e.g., the surrounding bulk soil, ectomycorrhizal root tips, or sporocarps), cultivating it, and then inoculating non-colonized seedlings with the isolated bacterium and the target fungus [30,36,37]. Moreover, inoculation trials considering other bacterial strains or co-inoculation with more than one bacterium at the same time should be tested. Furthermore, studies to investigate how repeated applications of bacterial inoculations as well as different bacterial inoculation doses could promote fungal mycorrhization are needed. Given that P. fluorescens is a biological, non-contaminant, and economical way of improving mycorrhization rates and plant quality at early developmental stages, our findings in the present study suggest that the co-inoculation of T. melanosporum-inoculated $Q$. faginea seedlings with $P$. fluorescens could have potential application in commercial nurseries.

Author Contributions: Conceptualization, Y.P., J.G.A., C.C., D.O. and J.A.B.; methodology, Y.P., J.G.A., C.C., D.O. and J.A.B.; software, Y.P. and J.G.A.; formal analysis, Y.P. and J.G.A.; investigation, Y.P. and F.B; resources, C.C., D.O and J.A.B.; data curation, Y.P., F.B. and J.G.A.; writing-original draft preparation, Y.P.; writing-review and editing, J.G.A., J.A.B., C.C., D.O.; supervision, J.G.A., J.A.B., C.C., D.O; project administration, C.C, D.O. and J.A.B.; funding acquisition, C.C., D.O. and J.A.B. All authors have read and agreed to the published version of the manuscript.

Funding: This research was funded by the Project INNOVATRUF (PECT El bosc, el primer recurs de l'economia verda-Fons Europeu de Desenvolupament Regional de la Unió Europea-Programa operatiu FEDER de Catalunya 2014-2020) and by the project UdL-Impuls.

Acknowledgments: Y.P. acknowledges the support of University of Lleida for her contract (UdL-Impuls), J.G.A. was supported by the Ramon y Cajal fellowship (RYC-2016-20528), D.O. received support from the 'Secretaria d'Universitats i Recerca del Departament d'Economia i Coneixement de la Generalitat de Catalunya' through the program of 'Doctorats Industrials', F.B.'s salary was partially funded by the Ministry of Science, Innovation and Universities through the National Agency of Research (PTA2017-14041-I) and J.A.B. benefitted from a Serra-Húnter Fellowship provided by the Generalitat of Catalunya. We thank Martina Peter (Swiss Federal Research Institute 
WSL) for her help facilitating the software WinRHIZO ${ }^{\circledR}$ and Vicente Medina Piles (Universitat de Lleida, Lleida (UDL)) providing the Epson Perfection V700 Photo Scanner system.

Conflicts of Interest: The authors declare no conflict of interest. The funders had no role in the design of the study; in the collection, analyses, or interpretation of data; in the writing of the manuscript, or in the decision to publish the results.

\section{References}

1. Bonito, G.M.; Gryganskyi, A.P.; Trappe, J.M.; Vilgalys, R. A global meta-analysis of Tuber ITS rDNA sequences: Species diversity, host associations and long-distance dispersal. Mol. Ecol. 2010, 19, 4994-5008. [CrossRef] [PubMed]

2. Mello, A.; Murat, C.; Bonfante, P. Truffles: Much more than a prized and local fungal delicacy. FEMS Microbiol. Lett. 2006, 260, 1-8. [CrossRef] [PubMed]

3. Büntgen, U.; Tegel, W.; Egli, S.; Stobbe, U.; Sproll, L.; Stenseth, N.C. Truffles and climate change. Front. Ecol. Environ. 2011, 9, 150-151. [CrossRef]

4. Le Tacon, F.; Marcais, B.; Courvoisier, M.; Murat, C.; Montpied, P.; Becker, M. Climatic variations explain annual fluctuations in French Périgord black truffle wholesale markets but do not explain the decrease in black truffle production over the last 48 years. Mycorrhiza 2014, 24, 115-125. [CrossRef]

5. Callot, G. La Truffe, la Terre, la Vie, INRA ed.; Quae: Versailles, France, 1999; 210p.

6. Hall, I.R.; Zambonelli, A. The Cultivation of Mycorrhizal Mushrooms-Still the Next Frontier! In Mushroom Science XVIII; Zhang, J., Wang, H., Chen, M., Eds.; China Agricultural Press: Beijing, China, 2012; pp. 16-27.

7. Hall, I.R.; Brown, G.T.; Zambonelli, A. Taming the Truffle; Timber Press: Portland, Oregon, 2007; 304p.

8. Andrés-Alpuente, A.; Sánchez, S.; Martín, M.; Aguirre, A.J.; Barriuso, J.J. Comparative analysis of different methods for evaluating quality of Quercus ilex seedlings inoculated with Tuber melanosporum. Mycorrhiza 2014, 24, 29-37. [CrossRef]

9. Donnini, D.; Benucci, G.M.N.; Bencivenga, M.; Baciarelli-Falini, L. Quality assessment of truffle-inoculated seedlings in Italy: Proposing revised parameters for certification. For. Syst. 2014, 23, 385-393. [CrossRef]

10. Fischer, C.R.; Colinas, C. Methodology for certification of Quercus ilex seedlings inoculated with Tuber melanosporum for commercial application. In Proceedings of the 1st International Conference in Mycorrhizae, Berkeley, CA, USA, 4-9 August 1996.

11. Le Roux, C.; Tournier, E.; Lies, A.; Sanguin, H.; Chevalier, G.; Dupponois, R.; Mousain, D.; Prin, Y. Bacteria of the genus Rhodopseudomonas (Bradyrhizobiaceae): Obligate symbionts in mycelial cultures of the black truffles Tuber melanosporum and Tuber brumale. SpringerPlus 2016, 5, 1085. [CrossRef]

12. Iotti, M.; Piattoni, F.; Zambonelli, A. Techniques for Host Plant Inoculation with Truffles and Other Edible Ectomycorrhizal Mushrooms. In Taming the Truffle; Timber Press: Portland, Oregon, 2007; pp. 145-161.

13. Buzzini, P.; Gasparetti, C.; Turchetti, B.; Cramarossa, M.R.; Vaughan-Martini, A.; Martini, A.; Pagnoni, U.M.; Forti, L. Production of volatile organic compounds (VOCs) by yeasts isolated from the ascocarps of black (Tuber melanosporum Vitt.) and white (Tuber magnatum Pico) truffles. Arch. Microbiol. 2005, 184, 187-193. [CrossRef]

14. Rivera, C.S.; Blanco, D.; Oria, R.; Venturini, M.E. Diversity of culturable microorganisms and occurrence of Listeria monocytogenes and Salmonella spp. in Tuber aestivum and Tuber melanosporum ascocarps. Food Microbiol. 2010, 27, 286-293. [CrossRef]

15. Pacioni, G.; Leonardi, M.; Aimola, P.; Ragnelli, A.; Rubini, A.; Paolocci, F. Isolation and characterization of some mycelia inhabiting Tuber ascomata. Mycol. Res. 2007, 111, 1450-1460. [CrossRef]

16. Frey-Klett, P.; Garbaye, J.; Tarkka, M. The mycorrhiza helper bacteria revisited. New Phytol. 2007, 176, 22-36. [CrossRef] [PubMed]

17. Gryndler, M.; Hršelová, H. Isolation of bacteria from ectomycorrhizae of Tuber aestivum Vittad. Acta Mycol. 2012, 47, 155-160. [CrossRef]

18. Sbrana, C.; Agnolucci, M.; Bedini, S.; Lepera, A.; Toffanin, A.; Giovannetti, M.; Nuti, M.P. Diversity of culturable bacterial populations associated to Tuber borchii ectomycorrhizas and their activity on T. borchii mycelial growth. FEMS Microbiol. Lett. 2002, 211, 195-201. [CrossRef] [PubMed] 
19. Barbieri, E.; Bertini, L.; Rossi, I.; Ceccaroli, P.; Saltarelli, R.; Guidi, C.; Zambonelli, A.; Stocchi, V. New evidence for bacterial diversity in the ascoma of the ectomycorrhizal fungus Tuber borchii Vittad. FEMS Microbiol. Lett. 2005, 247, 23-35. [CrossRef] [PubMed]

20. Barbieri, E.; Guidi, C.; Bertaux, J.; Frey-Klett, P.; Garbaye, J.; Ceccaroli, P.; Saltarelli, R.; Zambonelli, A.; Stocchi, V. Occurrence and diversity of bacterial communities in Tuber magnatum during truffle maturation. Environ. Microbiol. 2007, 9, 2234-2246. [CrossRef] [PubMed]

21. Benucci, G.M.N.; Bonito, G.M. The truffle microbiome: Species and geography effects on bacteria associated with fruiting bodies of hypogeous Pezizales. Microb. Ecol. 2016, 72, 4-8. [CrossRef]

22. Antony-Babu, S.; Deveau, A.; Van Nostrand, J.D.; Zhou, J.; Le Tacon, F.; Robin, C.; Frey-Klett, P.; Uroz, S. Black truffle-associated bacterial communities during the development and maturation of Tuber melanosporum ascocarps and putative functional roles. Environ. Microbiol. 2014, 16, 2831-2847. [CrossRef]

23. Deveau, A.; Antony-Babu, S.; Le Tacon, F.; Robin, C.; Frey-Klett, P.; Uroz, S. Temporal changes of bacterial communities in the Tuber melanosporum ectomycorrhizosphere during ascocarp development. Mycorrhiza 2016, 26, 389-399. [CrossRef]

24. Domínguez, J.A.; Martin, A.; Anriquez, A.; Albanesi, A. The combined effects of Pseudomonas fluorescens and Tuber melanosporum on the quality of Pinus halepensis seedlings. Mycorrhiza 2012, 22, 429-436. [CrossRef]

25. Mamoun, M.; Olivier, J.M. Effect of soil Pseudomonas on colonization of hazel roots by the ecto-mycorrhizal species Tuber melanosporum and its competitors. Plant. Soil 1992, 139, 265-273. [CrossRef]

26. Reyna, S. Truficultura Fundamentos y Técnicas; Mundi-Prensa: Madrid, Spain, 2012; 720p.

27. Mello, A.; Ding, G.C.; Piceno, Y.M.; Napoli, C.; Tom, L.M.; De Santis, T.Z.; Andersen, G.L.; Smalla, K.; Bonfante, P. Truffle brûlés have an impact on the diversity of soil bacterial communities. PLoS ONE 2013, 8, e61945. [CrossRef] [PubMed]

28. Duponnois, R.; Garbaye, J. Effect of dual inoculation of Douglas fir with the ectomycorrhizal fungus Laccaria laccata and mycorrhization helper bacteria (MHB) in two bare-root forest nurseries. Plant. Soil 1991, 138, 169-176. [CrossRef]

29. Gamez, R.; Cardinale, M.; Montes, M.; Ramirez, S.; Schnell, S.; Rodriguez, F. Screening, plant growth promotion and root colonization pattern of two rhizobacteria (Pseudomonas fluorescens Ps006 and Bacillus amyloliquefaciens Bs006) on banana cv. Williams (Musa acuminata Colla). Microbiol Res. 2019, 220, 12-20. [CrossRef]

30. Navarro-Ródenas, A.; Berná, L.M.; Lozano-Carrillo, C.; Andrino, A.; Morte, A. Beneficial native bacteria improve survival and mycorrhization of desert truffle mycorrhizal plants in nursery conditions. Mycorrhiza 2016, 26, 769-779. [CrossRef] [PubMed]

31. Dominguez, J.A.; Medina, M.; Berrocal-Lobo, M.; Anriquez, A.; Albanesi, A. The combined effects of Pseudomonas fluorescens CECT 844 and the black truffle co-inoculation on Pinus nigra seedlings. IForest 2015, 8, 624-630. [CrossRef]

32. Mediavilla, O.; Olaizola, J.; Santos-Del-Blanco, L.; Oria-de-Rueda, J.A.; Martín-Pinto, P. Mycorrhization between Cistus ladanifer L. and Boletus edulis Bull is enhanced by the mycorrhiza helper bacteria Pseudomonas fluorescens Migula. Mycorrhiza 2016, 26, 161-168. [CrossRef]

33. De Vita, P.; Avio, L.; Sbrana, C.; Laidò, G.; Marone, D.; Mastrangelo, A.M.; Cattivelli, L.; Giovannetti, M. Genetic markers associated to arbuscular mycorrhizal colonization in durum wheat. Sci. Rep. 2018, 8, 1-12. [CrossRef]

34. Wang, M.B.; Zhang, Q. Issues in using the WinRHIZO system to determine physical characteristics of plant fine roots. Acta Ecol. Sin. 2009, 29, 36-38. [CrossRef]

35. Agerer, R. (1987-2008) Colour Atlas of Ectomycorrhizae, 1st-13th ed.; Einhorn-Verlag: Munich, Germany, 2012.

36. Oh, S.Y.; Lim, Y.W. Effect of fairy ring bacteria on the growth of Tricholoma matsutake in vitro culture. Mycorrhiza 2018, 28, 411-419. [CrossRef]

37. Gryndler, M.; Beskid, O.; Hujslová, M.; Konvalinkovà, T.; Bukovskà, P.; Zemkovà, L.; Hršelová, H.; Jansa, J. Soil receptivity for ectomycorrhizal fungi: Tuber aestivum is specifically stimulated by calcium carbonate and certain organic compounds, but not mycorrhizospheric bacteria. Appl. Soil Ecol. 2017, 117-118, 38-45. [CrossRef]

38. Tarkka, M.T.; Drigo, B.; Deveau, A. Mycorrhizal microbiomes. Mycorrhiza 2018, 28, 403-409. [CrossRef] 
39. Frey-Klett, P.; Chavatte, M.; Clausse, M.L.; Courrier, S.; Le Roux, C.; Raaijmakers, J.; Martinotti, M.G.; Pierrat, J.C.; Garbaye, J. Ectomycorrhizal symbiosis affects functional diversity of rhizosphere fluorescent pseudomonads. New Phytol. 2005, 165, 317-328. [CrossRef] [PubMed]

40. Kloepper, J.; Leong, J.; Teintze, M.; Schroth, M.N. Enhanced plant growth by siderophores produced by plant growth-promoting rhizobacteria. Nature 1980, 286, 885-886. [CrossRef]

41. Batista, B.D.; Lacava, P.T.; Ferrari, A.; Sousa Teixeira-Silva, N.; Bonatelli, M.L.; Tsui, S.; Mondin, M.; Watanabe Kitajima, E.; Odair Pereira, J.; Azevedo, J.L.; et al. Screening of tropically derived, multi-trait plant growthpromoting rhizobacteria and evaluation of corn and soybean colonization ability. Microbiol. Res. 2018, 206, 33-42. [CrossRef] [PubMed]

42. Labbé, J.L.; Weston, D.J.; Dunkirk, N.; Pelletier, D.A.; Tuskan, G.A. Newly identified helper bacteria stimulate ectomycorrhizal formation in Populus. Front. Plant. Sci. 2014, 5, 1-10. [CrossRef]

43. Rincón, A.; Ruiz-Díez, B.; García-Fraile, S.; Lucas-García, J.A.; Fernández-Pascual, M.; Pueyo, J.J.; de Felipe, M.R. Colonisation of Pinus halepensis roots by Pseudomonas fluorescens and interaction with the ectomycorrhizal fungus Suillus granulatus. FEMS Microbiol. Ecol. 2005, 51, 303-311. [CrossRef]

(C) 2020 by the authors. Licensee MDPI, Basel, Switzerland. This article is an open access article distributed under the terms and conditions of the Creative Commons Attribution (CC BY) license (http://creativecommons.org/licenses/by/4.0/). 